DOI: $10.17951 / f f .2018 .36 .2 .131-145$

\begin{tabular}{|c|c|c|}
\hline U N I & $\begin{array}{l}\text { ANNALE } \\
\text { MARIAE C } \\
3 \text { LIN - POI }\end{array}$ & \\
\hline VOL. XXXVI & SECTIO FF & $2-2018$ \\
\hline
\end{tabular}

KRZYSZTOF ANTONIAK

Katolicki Uniwersytet Lubelski Jana Pawła II

ORCID ID: https://orcid.org/0000-0002-0273-8151

\title{
L.A. Confidential as a Re-Creation of American Noir Tradition
}

Odtworzenie amerykańskiej tradycji noir na przykładzie L.A. Confidential

James Ellroy is one of the most prominent writers of the late twentieth century concerned with noir themes. His most famous novels, the so-called L.A. Quartet (The Black Dahlia, The Big Nowhere, L.A. Confidential, and White Jazz), are set in the 1940s and 1950s in Los Angeles. The writer depicts police officers, corrupt officials, psychopathic killers and mafia connections, presenting Los Angeles as a maze (Mayer and McDonnell, 2007:254). Two of his novels, L.A. Confidential and The Black Dahlia, appeared to be so successful that they have been adapted by such prominent film directors like Curtis Hanson and Brian De Palma. In this article, I will focus my analysis on L.A. Confidential and Hanson's masterpiece.

According to Geoff Mayer and Brian McDonnell, Hanson's adaptation of the novel L.A. Confidential, may be considered "one of the most thought-provoking, profound, and moving of all neo-noir films" (2007:255). Even though it differs significantly from the literary original, the narrative of the film has not lost its appeal. The changes introduced by the director did not corrupt the story and, one could say, made it even more fascinating. This article will discuss the assumption that not only does L.A Confidential employ noir themes and character stereotypes, but it also plays with them, altering noir stylistic standards and re-inventing new types of a hard-boiled detective, hence re-creating American noir tradition. In order to demonstrate how L.A. Confidential's film adaptation can be classified as neo-noir film at the same time breaking the rules of classic film noir, this work will discuss certain features of the film. The aspects that will be discussed concern retro-noir setting and L.A. noir elements, in other words, how the city is presented by Ellroy 
and Hanson. Most importantly, the article will scrutinize the portrayals of the police officers, juxtaposing them with an archetype of a hard-boiled detective. Moreover, the work will also focus on the figure of femme fatale, or rather her pastiche, and will analyze the role that she plays. All in all, the article will show how the novel and film employ noir stylistic elements, modifying them, thus altering the classic American noir tradition.

\section{NEO-HARD-BOILED DETECTIVE}

Before analyzing the extent to which the detectives portrayed in L.A. Confidential can be defined as hard-boiled detectives, a few main features of a hardboiled protagonist must clearly be stated. Jerold J. Abrams underlines that a truly hard-boiled character is always isolated:

$[\mathrm{H}] \mathrm{e}$ lives entirely alone and has no friends. And this certainly makes his already asocial nature all the worse. The hard-boiled detective is isolated and angry, hopeless and amoral - he's a dark character in an even darker labyrinth. He's unrefined and in many ways perhaps unlikable. But, then, why should he care? The hard-boiled detective is excessively detached [...]. (2006:75)

The relationships between him and other people are usually very complicated, since he is an asocial type of a person. Deborah Knight focuses on different traits, emphasizing that it is pursuing justice and need to restore order that influence a hard-boiled detective's actions:

[T] here is something special about the hard-boiled detective, as opposed to the classic detective, something that has to do with his personal and emotional investment in the events and people he is investigating, an investment that requires that he act to ensure justice is done even after the crime has been solved. (2006:208)

She also enumerates one more thing that is characteristic of such a detective: reasoning skills. The critic argues that extraordinary reasoning skills are essential in order to discover "whodunit" (2006:209). It is interesting to analyze the portrayals of the police officers as presented in the novel and the film adaptation with the aim of showing how a classic hard-boiled detective has been re-invented. 


\section{Jack "Trashcan" Vincennes}

In L.A. Confidential it is the cops, not private eyes, that are the central figures leading the investigation. The first type of the detective is Jack "Trashcan" Vincennes, played by Kevin Spacey. In the film, this "shallow publicity hound exploiting the misery of others" (qtd. in Shefrin, 2005:177) is immersed in the corruption of L.A. (Douet, 2017). Not only does he accept bribes, but he also steals marijuana from a crime scene. His lust for money and fame obscured his real role as a cop. At the beginning of the movie, Jack is not interested in restoring the order in the city, since it is disorder that brings him lots of opportunities to present himself as a star in the media. Jack is an informant who provides Sid Hudgens with the details where and when a crime has been or is being committed, and in return the reporter portrays him as a star, a real cop who fights the crime in the city. However, throughout the movie Jack undergoes a transformation. During the conversation with a corrupt captain Dudley he actually says:

JACK. I messed something up. I'm trying to make amends.

DUDLEY. Don't start trying to do the right thing. You haven't had the practice.

(L.A. Confidential)

These are basically the last words that Jack hears before being shot by Dudley. He came to him as a friend to ask about his help in the investigation which clearly was not in Dudley's best interest.

What Hanson did in the film was certainly unexpected. The director creates a character that could not be less hard-boiled, yet he shapes him into someone who could have actually evolved into a hard-boiled detective, yet does not live to become one. Instead, he becomes a victim of a corrupt system, the one that he himself abused. He has been sucked into the maze of the city. The first type of the detective created by Hanson does not really meet requirements to be a hard-boiled protagonist, yet he does struggle to transform and shifts his role from being a celebrity into being an honest cop.

In the novel, however, Jack's story is quite different, yet he is also portrayed as a cop who fights his demons and, in the end, pursues justice. Working for Administrative Vice, he arrests narcotics offenders only to become addicted himself. He is even dubbed "Trashcan" by his fellow police officers. One day, while on duty, he shoots two tourists mistaking them with the " $\mathrm{H}$ " men whom he chases. At that point, he realizes that as an officer of the law who should keep order, he failed not only to save the civilian lives, but it was him who turned out to be a threat. Being under the influence of strong drugs and alcohol, he took lives of innocent people. 
Even though he was to blame for their deaths, he goes unpunished as the police accuse the smugglers for his sins. He ends up as a hero, wounded during the chase:

A shot ripped his shoulder; a shot grazed his legs. He crawled under the car; a shitload of tires squealed; a shitload of people screamed. An ambulance showed up; a bull dyke Sheriff's deputy loaded him on a gurney. Sirens, a hospital bed, a doctor and the dyke whispering about the dope in his system - blood test validated. Lots of drugged sleep, a newspaper on his lap: "Three Dead in Malibu Shootout - Heroic Cop Survives." The "H" guys escaped clean - the deaths pinned on them [...]. The shapes weren't the nigger's backup - they were Mr. and Mrs. Harold J. Scoggins, tourists from Cedar Rapids, Iowa, the proud parents of Donald, seventeen, and Marsha, sixteen. (Ellroy, 1994:37)

The luck was on Jack's side, since the children of the dead did not want autopsy as, being Seventh-Day Adventist, they considered it sacrilege. Without it there was no proof that it was the bullets from his gun that killed the parents. However, even though he is not held responsible for the deed, he feels the strong need to change his life and redeem his guilt.

His wounds healed. He quit drinking. He quit taking dope [...]. He marked abstinent days on his calendar, worked his deal with Sid Hudgens, built his name as a local celebrity. [...] Sid got him the "technical advisor" job with Badge of Honor [...]. His first check ran two hundred; he included a letter: "Anonymous Friend," a spiel on the Scoggins tragedy. He called the bank a week later: the check had been cashed. He'd been financing his free ride ever since. (Ellroy, 1994:38-39)

Nevertheless, just like in the film, Jack does not live to solve his last case and prove to be a true hard-boiled detective, as he his killed, unlike in the adaptation, not by Dudley but by a criminal associated with Dudley Smith whom he is chasing.

\section{Edmund Exley}

The next type of a detective presented in L.A. Confidential is Edmund Exley. This "ambitious opportunist masquerading as an idealist" (qtd. in Shefrin, 2005:177) possesses some of the characteristics of a classic hard-boiled detective; however, also in this case the detective is presented quite ambiguously. Exley always "goes by the book" (Mayer and McDonnell, 2007:255), at the same time being open to taking advantage of the situation in order to climb the career ladder. Like a hard-boiled detective, he is isolated and asocial, perceived as a "troublemaker and socially separate" (Douet, 2017). He also has good reasoning skills and is smart enough to intimidate suspects and get their testimonies. Nevertheless, at least at the beginning, he does not have the guts to use the violence when needed. 
The answers to all of those questions that Dudley in the film and Ed's father in the novel ask Ed is "no":

You're a political animal. You have the eye for human weakness, but not the stomach [...]. Would you be willing to plant evidence on a suspect you knew to be guilty to insure an indictment? [...] Would you beat a confession out of a suspect you knew to be guilty? Would you shoot a hardened criminal in the back [...]? Stick to assignments where you don't have to make those choices. [...] At least get rid of the glasses. I can't think of a man in the Bureau who wears them. (L.A. Confidential)

Just like Jack, throughout the movie Ed also undergoes a transformation. He becomes a person, who is eventually capable of shooting his corrupt unarmed boss in the back, thus breaking the rules which he used to stick to. He understands that to restore the order, sometimes you cannot be a law-abiding person. At some point, Ed Exley fulfils almost all the requirements that have been mentioned characterizing a hard-boiled detective: he is isolated and detached, asocial, he wants to restore order and is witty. Nonetheless, Hanson decides to subvert the audience's expectation and just at the end of the movie, shows us that, precisely like in hard-boiled fiction and film noir, justice cannot win. Ed comes back to being an opportunist, who decides to back up the fictional version of the events, or to be more precise, comes up with it himself in order to be decorated with a medal of bravery for fighting hand in hand with Dudley against other perpetrators. The audience sees that even though the corrupt Dudley is shot, he is pronounced to be a hero, since this is the reality of Los Angeles - the order cannot be restored.

The plot of the novel, once again, varies from the one in the movie adaptation. Instead to his late father, Ed is all the time compared to his late brother who died on duty. Since his father has not been killed by Dudley, the will to catch Smith, who is also the villain in the novel but not responsible for Preston Exley's death, is less personal, less of a revenge. In the beginning of the book, never does Edward hear that he is as outstanding as his brother used to be. His lieutenant describes him as follows:

You're not one of the guys. You're not a strongarm type. You're not Bureau. [...] You're good, and in time you might be really good. And I don't doubt your killer instinct for a second. But your father was ruthless and likable. And you're not, so... (Ellroy, 1994:17-18)

What worries him even more is that his own father does not believe in him: "the truth is that I don't think you have the eye for human weakness that makes a good detective" (1994:19). Little does he know, that in fact it is his father who has earned money and gained fame thanks to his acquaintance with one of the criminals. Just as in the film, in the end Ed is also honoured with medals for his bravery, even though Dudley manages to escape justice and only some of the criminals are killed and others, including his own father, commit suicide. Nonetheless, Ed swears to 
catch Smith, even if he has to resort to the methods, including the dirty money which he stole, that he used to condemn. He says:

"Fuck Dudley sideways. I've got a shitload of Patchett's money for a bankroll, and I'll burn down that Irish cocksucker if it's the last fucking thing I ever do. Lad."

[...] "May I make an observation, Inspector?"

"Sure."

"You sound more like Bud White every day." (Ellroy, 1994:472)

\section{Wendell "Bud" White}

The last type of the detective that this article will analyze is Bud White. In Ed's opinion, he is nothing more than "a homicidal thug" (Ellroy, 1994: 64). Just like a classic hard-boiled detective, Bud is detached and lonely. Although it is true that he gets on well with fellow cops, he keeps himself to himself. The person that he trusts and before whom he reveals his true feelings is Lynn Bracken, a character which will later on be discussed in detail. Like a hard-boiled type, he falls in love with a femme fatale.

Regarding his reasoning skills, it must be said that his better at "beat[ing] a confession out of a suspect" (L.A. Confidential) than using verbal persuasion. Nevertheless, he is probably the most just and honest detective presented in the film and the novel:

On a liquor store stakeout, Officer White (who is plagued by old football injuries) chased a fleeing armed suspect for a half mile. The suspect fired repeatedly back at Officer White, who did not return his fire for fear of hitting innocent civilians. The suspect took a woman hostage and held a gun to her head, which held off the backup officers who had caught up with Officer White. White then walked through a side alley while his partners attempted to calm the suspect down. The suspect refused to release the woman, and White shot and killed him at point-blank range. The woman was unharmed. (Ellroy, 1994:83)

Bud appears not to think about himself, but feels an urgent need to protect people, mostly women.

However, what triggers his actions is a strong will to retaliate against the criminals, especially the ones abusing women, which is caused by his childhood trauma. Therefore, what motivates him is not necessarily the urge to restore the order because this is what should be done, but the revenge. It is disputable whether Bud White is a hard-boiled detective or just a vigilante. While talking to Lynn, he admits that it may have been the revenge which convinced him to become a cop, not the will to abide the law; he has low self-esteem and acknowledges that people do not treat him seriously, because they doubt he could come up with something clever: 
BUD. I was 12. My dad went after my mother with a bottle. I got in the way [...]. He tied me to the radiator. I watched him beat my mother to death with a tire iron and he left me there. Three days before a truant officer found us. They never found the old man.

LYNN. Is that why you became a cop? To get even?

BUD. Maybe.

LYNN. Do you like it?

BUD. I used to. Now it's all strong-arm, sitting duck stuff. If I could get a chance to work homicide like a real detective [...]. Something's wrong with the Nite Owl. I just can't prove it, that's all. I'm not smart enough. I'm just the guy they bring in to scare the other guy shitless. (L.A. Confidential)

In the book, White also underestimates his ability of analytical thinking. He desires to be a detective, but he worries that he is always under someone's supervision and other people do not see his mental potential, what they see is just his fists. He wonders: "BEING A DETECTIVE - NOT A HEADBASHER - ON HIS OWN. He fed himself drunk talk for guts: It ain't like you're your own man. It ain't like you're your own man. It ain't like you're your own man" (Ellroy, 1994:163). He refuses to accept the award after his pursuit of a criminal in which he was wounded and in result will probably never speak again. His attitude shows that he truly is the most devoted and honest detective of all:

Bud White refused to die. He remained in intensive care at Fontana General Hospital. He survived massive shock, neurological trauma, the loss of over half the blood in his body. Lynn Bracken stayed with him. He could not speak, but responded to questions with nods. Chief Parker presented him with his Medal of Valor. White freed an arm from a traction sling, threw the medal in his face. (Ellroy, 1994:461)

All of the detectives transgress the classic definition of a hard-boiled detective. To a certain extent, all three possess certain qualities that would classify them as hardened investigators. What makes them even more interesting than a typical hard-boiled character are the alterations that both Ellroy and Hanson have made, re-inventing new models of a noir detective, hence re-creating American film noir tradition. What is even more unusual is the fact that when Ed and Bud finally join forces, they complement each other: "the Exley/White alliance transcends the traditional detective paradigm - only by joining forces are the »tarnished protagonists « able to finally read the »unreadable terrain «" (qtd. in Shefrin, 2005:177). Amy Taubin also jokingly remarks that: "Exley has the brain to match White's guts - together they'd make a fabulous man" (1997:7). 


\section{L.A. CONFIDENTIAL AS RETRO-NOIR}

Andrew Spicer defines retro-noir films as follows: "retro-noirs are neonoirs that consciously re-create the "classic' 1940-59 period" (Spicer, Historical Dictionary, 2010:259). Since L.A. Confidential is set in 1952 (Ellroy, 1994:164), but was shot in 1997, it can clearly be classified as a retro-noir film. However, the film lacks nostalgia, a feature that is ascribed to retro-noirs. Hanson claims that the decision to avoid "the lens of nostalgia" (qtd. in Taubin, 1997:8) was deliberate. He wanted to create "a period piece that would be funny and dark, yet with contemporary feel" (Taubin, 1997:8). The director admits that "[he] wanted this to be a movie set in the splashy 50's, [...] lurid and fun [...], noir in the broadest sense, meaning darkness under the bright" (qtd. in Taubin, 1997:8). The effect was achieved by the colours, which are rather soft and greyish, yet not black and white as they used to be in the classic film noir.

Even though Hanson's adaptation is devoid of nostalgia and is not shot in blackand-white, it casts only white actors as the police officers, which is also indicative of retro-noirs. Krystian Zając states that retro-noir presents white males as dominant, white females as passive and marginal, whereas other races are just a background (2010:193). He also adds that it is the relationships between white males that play the most important role in L.A. Confidential (2010:196). The film has been hilariously described as "the whitest movie of all time, [...] with the most Anglos L.A.'s seen since the last Metallica concert" (qtd. in Shefrin, 2005:174). All things considered, L.A. Confidential can be classified as a retro-noir film, yet it does lack some features of the classic film noir, as a result of the director's conscious alteration. What makes the film a retro-noir is, among others, the presence of the pastiche of femme fatale. Unlike in the film, where there is only one female character, the novel describes three women, each of which is, in her own way, fascinating and seductive.

\section{THE ROLE OF WOMEN IN L.A. CONFIDENTIAL}

In the film adaptation, when it comes to the female characters, or to be more precise, femme fatale, there is only one central figure. Lynn Bracken is a prostitute whose appearance bears similarities to a famous actress, Veronica Lake. Hanson says: "[her] house is like a stage where she's selling the illusion of the romance of Hollywood" (qtd. in Shefrin, 2005:179). While publicly she plays a star that is desired by every man in the city, in a privacy of her own bedroom, she keeps memorabilia from her childhood, which presents her as a fragile woman, missing her hometown in Arizona. 
In Writing the New Noir Film, Sharon Y. Cobb notes that the femme fatale "represents a better life. She is usually wealthy, beautiful, intelligent and illusive. However, the femme fatale always has her own agenda and, after using the protagonist for her own gains, she will deceive him" (qtd. in Douet, 2017). Lynn Bracken is clearly not the case. She is a victim "of the duplicitous society [...], performing sexualized gender roles for the men who control [her]" (Douet, 2017). Even though she is in love with Bud, she cheats on him, because she is told to do so by the brothel-keeper. Jans B. Wager remarks that retro-noirs present their own version of femme fatale, who is fragile and dependent on men. She uses the term "pastiche", when describing a retro-noir version of femme fatale. A pastiche of femme fatale looks like a femme fatale from a classic film noir, but she does not behave like one: "she walks the walk, talks the talk, and certainly dresses the part. But unlike the dangerous dames of film noir, she in no way drives the narrative or influences the outcome of events" (Wager, 2005:84). Analyzing retro-noir films it is easily noticeable that they rarely portray a real femme fatale. They rather present a caricature of her. These contemporary works of cinematography in a way erased the vision of an imperious and dangerous women from their plots. Wager states:

Whereas once noir provided spectators with strong women, today's retro-noir presents audiences with weak or passive women, with visions of white male brutality and female powerlessness and objectification. Retro-noirs offer a toned-down, bland, and domesticated version of femininity [...]. (2005:88)

While neo-noir gives female characters a chance to develop without being oppressed, retro-noir films do not grant them this opportunity.

As regards Ellroy's novel, there are three main female characters. One of them is Lynn Bracken, yet her portrayal differs subtly from the film adaptation. The main reason behind it is that Lynn has agency to make decisions about herself. She is not forced in any way to cheat on White. One could say that her decision to do so makes her more of a femme fatale rather than the pastiche, yet in any other aspect of her life she is dependent on men, therefore, it is risky to call her a femme fatale. Even though Lynn Bracken loves Bud White and stays by his side after he is "a cripple with a pension" (Ellroy, 1994:479), she feels the bond with Edward and does not regret the betrayal. In fact, she cheats on Bud even after he discovered it. In her diary she writes:

E.E. makes love like my Wendell, like he never wants it to end, because when it ends he will have to return to what he is. He is perhaps the only man I have ever met who is as compromised as I am, who is so smart, circumspect and cautious that you can always see his wheels turning and thus wish you could always talk in the dark so that face value would be less complex. He is so smart and pragmatic that he makes W.W. appear childish and thus less heroic than he really is. (Ellroy, 1994:407) 
She admires Exley and admiration for men is not really an emotion that a femme fatale would feel. Therefore, although she chooses to cheat on "her Wendell" and is not forced to do it as is the case in the film, it does not make her a femme fatale.

Another female character in the novel is Inez Soto, the Mexican-American woman raped by the "niggers" who were wrongly accused of the slaughter in the Nite Owl. Even though she is the victim, it appears that Inez is a very resourceful woman. She becomes very close to both Ed and Bud. Inez appears to have feelings for White and cheats on Exley with him, and yet she has a years-long relationship with Edward, although she knows that he "would never violate departmental regs by cohabitating with her" (Ellroy, 1994:267), as lieutenant Art De Spain puts it. She complains to Edward that he does not treat her like White does:

Exley, I know you. You don't give a damn about justice, you just care about yourself [...]. You treat me like you want to love me, then you give me nothing but money and social connections, which you've got plenty of and won't miss. You take no risks for me, and Officer White risks his estúpido life and doesn't weigh the consequences, and when I get better you'll want to fuck me and set me up someplace where you won't have to be seen in public with me, which is revolting to me. (Ellroy, 1994:238)

Inez Soto is portrayed as a victim, raped and used by Edward Exley who needs her testimony to close the case. He sleeps with her, gives her money and seems to care about her, yet does not marry her, since it would undermine his authority, as she is Mexican-American. One could say that Inez Soto is another embodiment of a pastiche of femme fatale, but it is essential to add that her portrayal is also altered by James Ellroy. She is a retro-noir, fragile version of femme fatale, but she has her own agenda. What she wants from the very beginning is to have the men who raped her killed. She uses Exley to shoot African-Americans misinforming him about the events of that night. She says: "The negritos who hurt me couldn't have killed the people at the Nite Owl, because they were with me the whole night. They never left my sight. I lied because I didn't want you to feel bad that you'd killed four men for me" (Ellroy, 1994:275). She is aware of the fact that if Ed had known the truth, he would have never killed those men. One could say that being a tool herself, she used a man for her own agenda and accomplished what she wanted.

Karen Morrow, Jack Vincennes' wife, is the most fragile of all the three women. She comes from a rich family and falls in love with Jack. Having been using the drugs, she is saved by the police officer and, as she believes, owes her life to him. Flirting with him, she gives him a speech:

[D]on't look at me, because I'm flustered. One, you got me away from taking pills. Two, you convinced my father to send me abroad, where I got a damn good education and met nice people. 
Three, you arrested that terrible man who sold me the pills [...]. Four, what I wasn't going to mention, is that Les Weiskopf gave girls pills for free if they slept with him. Father was stingy with my allowance and sooner or later I would have done it. So there - you kept my goddamned virtue intact. (Ellroy, 1994:42)

Finally, she accepts Jack's proposal and becomes Mrs. Vincennes only to end up as a miserable wife of a man who once again becomes an alcoholic, gets depressed because of the unclosed case that he works on, cheats on her with prostitutes and does not tell her the truth about his past. Stuck in marriage, she does not leave him. Karen has the least in common with a true femme fatale and meets all the requirements for a retro-noir pastiche. While the previously mentioned characters have been given some freedom of choice, Karen does not forsake her husband. She forgives him when she discovers the truth about him and cries on his funeral. Compared to Lynn and Inez, she does nothing against her man and leaves him notes saying how sorry she is after every fight they have.

Both in Ellroy's novel and Hanson's film the women protagonists are not neo-noir femme fatales. Even if they make her own decisions and sometimes lie to their partners or cheat on them, they are, all in all, fragile and dependent on them. However, one must acknowledge that Ellroy's portrayals of Lynn Bracken and Inez Soto show the author's alteration and modification of the retro-noir woman, inventing a new paradigm of femme fatale, who is more emancipated than a retro-noir pastiche, but is not a neo-noir femme fatale per se.

\section{THE CITY OF LOS ANGELES}

As regards the city itself, Los Angeles "becomes a functioning character in the film" (Mayer and McDonnell, 2007:255). One can notice its importance from the very beginning of the movie. Hanson gives voice to Sid Hudgens (Danny DeVito) who plays the role of a reporter in the Hush-Hush tabloid and is a substitute of a first person narrator which was usually employed to the classic hard-boiled fiction. Already in the film's opening scene, the audience sees a collage of documentary images, depicting Los Angeles in the 1950s and showing what a dream city it is. The voiceover adds a commentary:

Come to Los Angeles. The sun shines bright, the beaches are wide and inviting, and the orange groves stretch as far as the eye can see. There are jobs aplenty and land is cheap. Every working man can have his own house, and inside every house, a happy all-American family. You can have all this, and who knows, you can even be discovered, become a movie star, or at least see one. Life is good in Los Angeles. It's paradise on earth. That's what they tell you anyway, because they're selling an 
image. They're selling it through movies, radio and television. In the hit show Badge of Honor, the L.A. cops walk on water, as they keep the city clean of crooks. Yup, you'd think this place was the Garden of Eden. But there's trouble in paradise. (L.A. Confidential)

Obviously, just after this short introduction the viewers discover that the city is actually full of contradictions. Gary J. Hausladen and Paul F. Starrs argue that it is precisely the contradictions which the urban-based genre offers that "set a story line in motion" (2005:48). The adaptation depicts the post-war L.A. as a city of ambiguities: on the one hand, it presents itself as a paradise, yet on the other, it is corrupt and sinister. Not only is it organized crime that shapes a seamy side of the city, but it is also its authorities, the police officers, highly-ranked officials who should protect the city, but instead, corrupt it (Hausladen and Starrs, 2005:60).

Raymond Chandler used the words "mean streets" (1950:18), while referring to the streets of Los Angeles. Nicholas Christopher applies the term "labyrinth," underlining that in order to understand "the psychological and aesthetic framework of the film noir," one has to be aware of the "three corresponding and interlocking levels" of the labyrinth, in other words the city (Christopher, 1997:16-17). Hausladen and Starrs explain the levels as follows:

The city serves first as a physical maze of networks, roads and buildings; it stands second as a metaphor for the human condition in which characters intersect and interact; third, a city reflects a hero's mental and psychological struggles (2005: 48).

All these three levels are present in the adaptation.

The streets of Los Angeles are full of criminals and smugglers. The city appears to be the place, where when walking alone, one can lose their lives for no reason. Different races portrayed as savages and under-people craving for human blood. Finally, Hollywood itself - a place of deceit, where nothing is as it seems. Truly one can agree that the city, where the police are crooked and criminals themselves, where a police officer kills two innocent tourists and goes unpunished, where the head of the department deals with drugs and is guilty of at least a few homicides, may be compared to a labyrinth and a jungle. As for the hero's mental breakdowns, it has been discussed that all of the three described police detectives struggle with their lives. They struggle with their work, their private lives and with themselves. Los Angeles indeed is the city of noir. 


\section{ON-SCREEN VIOLENCE AND GORY DEPICTIONS OF HOMICIDE}

Hanson meticulously captured the ambiance and landscape of 1950s' Los Angeles, accentuating its contradictions. However, Hausladen and Starrs write:

L.A. Confidential also underscores the increase in the amount of violence shown on screen in these kind of films. [...] [I]n the classic period, as in the case of The Big Sleep, the actual blood and gore are kept to minimum. In L.A. Confidential, however, the level of on-screen violence increases dramatically in both the amount of violence and the graphic nature of its depiction. (2005:60)

The director, once again, adds his own touch to the retro-noir production, breaking the rules of film noir, thus exposing its audience to violence.

In his novel, Ellroy does not omit detailed descriptions of bloody murders, which is also indicative of a change in the hard-boiled fiction and uncommon in Chandler's or Hammett's works. This is one of the passages describing corpses:

Billy Dieterling on a white couch soaked red. A knife in his throat; two knives in his stomach. His scalp on the floor, stuck to the carpet with an icepick. A few feet away: a fortyish white man disembowelled, eviscerated, knives in his cheeks, two kitchen forks in his eyes. Drug capsules soaking in floor blood. (Ellroy, 1994:440)

Such a description is not rare in Ellroy's book as well as the screenshots presented above are not uncommon in Hanson's adaptation. The film alludes more to the cinema of the 1940s and 1950s which was described in the first chapter rather than to Chandlerian descriptions of "unbloody" murders.

\section{$* * *$}

In conclusion, L.A. Confidential can certainly be classified as noir, since it employs noir themes and stereotypical characters. However, it must be stated that both the film and the novel go beyond the categorization, since they alter noir stylistic standards and re-invent new types of a hard-boiled detective. Even though L.A. Confidential's film adaptation can be classified as retro-noir, it lacks nostalgia, mainly because Hanson wanted it to be lurid but also fun. Moreover, the novel as well as the film can be categorized as L.A. noir, since they are set in Los Angeles, yet the level of violence presented on-screen and described in the book is rather unusual for L.A. noirs such as The Big Sleep. Additionally, the police officers depicted in the adaptation transgress the definition of a classic hard-boiled detective, evolving into a new model of an investigator. Finally, L.A. Confidential portrays a pastiche of femme fatale, which is characteristic of retro-noir, yet stands in contrast to an 
image of a classic noir. All things considered, because of the modification of noir themes and re-invention of a hard-boiled detective archetype, L.A. Confidential may be perceived as a re-creation of American noir tradition.

\title{
BIBLIOGRAFIA PODMIOTOWA
}

Ellroy, J. (1994). L.A. Confidential. London: Arrow Books Limited.

Hanson, C. (1997). L.A. Confidential. Burbank: Warner Bros.

\section{BIBLIOGRAFIA PRZEDMIOTOWA}

Abrams, J.J. (2006). From Sherlock Holmes to The Hard-Boiled Detective. In: M.T. Conrad (ed.), The Philosophy of Film Noir (pp. 69-88). Lexington: The University Press of Kentucky.

Chandler, R. (1950). The Simple Art of Murder. Boston: Houghton Mifflin.

Christopher, N. (1997). Somewhere in the Night: Film Noir and the American City. New York: Free Press.

Douet, A. (2017). Representations of Los Angeles: Blade Runner and LA Confidential. From: www. academia.edu/10876889 (access: 14.09.2017).

Hausladen, G.J., Starrs, P.F. (2005). L.A. Noir. Journal of Cultural Geography, 23(1), pp. 43-69.

Knight, D. (2006). On Reason and Passion in The Maltese Falcon. In: M.T. Conard (ed.), The Philosophy of Film Noir (pp. 207-221). Lexington: The University Press of Kentucky.

Mayer, G., McDonnell, B. (2007). Encyclopedia of Film Noir. London: Greenwood Press.

Shefrin, E. (2005). Le Noir et le Blanc: Hybrid Myths in Devil in a Blue Dress and L.A. Confidential. Literature/Film Quarterly, 33(3), pp. 172-181.

Spicer, A. (2010). Historical Dictionary of Film Noir. Plymouth: The Scarecrow Press, pp. 164-165, 259.

Taubin, A. (1997). L.A. Lurid. Sight and Sound, 7, pp. 7-9.

Wager, J.B. (2005). Dames in the Driver's Seat: Reading Film Noir. Austin: The University of Texas Press.

Zając, K. (2010). Ideologia i ikonografia w filmach retro-noir. Studia Filmoznawcze, 31, pp. 189-206.

\begin{abstract}
ABSTRAKT
Elementy literatury hard-boiled i filmu noir są obecne we współczesnej literaturze i mediach wizualnych, ale motywy i postacie z klasycznych tekstów noir zostały odkryte na nowo. Artykuł udowadnia, że film L.A. Confidential może być postrzegany jako odtworzenie amerykańskiej tradycji noir, a powieść Jamesa Ellroya zaklasyfikowana jako literatura hard-boiled. Autor analizuje postacie detektywów przedstawione zarówno w książce, jak i w filmie oraz bada dzieło w kontekście retronoir, skupiając uwagę na postaci femme fatale, roli miasta i sposobie przedstawienia brutalności.
\end{abstract}

Słowa klucze: noir, hard-boiled, L.A. Confidential, James Ellroy 


\begin{abstract}
In contemporary literature and visual media one may encounter many references to hard-boiled fiction and film noir, yet the themes and characters depicted in the classic texts have been reinvented and altered. This article argues that L.A. Confidential may be perceived as a re-creation of American noir tradition and intends to prove that James Ellroy's L.A. Confidential may be classified as hardboiled literature. Moreover, it scrutinizes the figures of detectives presented in both the book and the film, and analyzes the work in terms of retro-noir, focusing attention on the figure of femme fatale, the notion of the city and the on-screen violence.
\end{abstract}

Keywords: noir, hard-boiled, L.A. Confidential, James Ellroy 